THURSDAY, FEBRUARY 25, I892.

\section{THE SCIENCE MUSEUM AND THE TATE GALLERY.}

$W^{\mathrm{E}}$ are informed that various Government Departments are now considering the many questions raised by the Tate Gallery controversy in the real spirit of scientific inquiry - that is, they are at last attempting to deal with the facts, and they are consulting some people who ought to know something about them.

As the President and Officers of the Royal Society, and many other representative men throughout the country, have stated their opinion on the matter to Lord Salisbury in a memorial last year; and as they were pretty certain to have known the facts before they committed themselves to any statement involving them in great responsibility if they were wrong; the friends of science can only rejoice that at last the Government Departments are dealing with the matter in a scientific way.

The facts are as follows. In our Museum arrangements, while books and pictures--or, in other words, literature and art-are thoroughly represented, from the Museum point of view, on a scale worthy of the nation, only three branches of science-natural history, geology, and mineralogy - have so far been provided for, and by the Natural History Museum. This was pointed out about twenty years ago by the Duke of Devonshire's Commission; and the many advantages which would be certain to accrue to an industrial nation like ours, from collections representing the various physical, chemical, mechanical, and metallurgical sciences and their applications to industry, were very clearly referred to.

The Government, one may almost say, of course, took no notice of this important recommendation, or next to none. In 1876 the Royal Commissioners for the Exhibition of $185 \mathrm{I}-\mathrm{a}$ body thoroughly well capable of judging of the importance of the Duke of Devonshire's recommendation-showed their opinion of its importance by offering a plot of ground stretching from Queen's Gate to Prince's Gate, and £100,000 to build this Science Museum. This offer, the Government of the day-most of the Governments of the day knowing and caring little about science, although they are so glad to receive donations for art-declined. So matters went on, Committee after Committee being appointed, reporting, and having their deliberations ignored, until at last, as a result of a Committee appointed by the Treasury itself, the plot of ground which the Government might years ago have had for nothing, was purchased, and purchased, of course, in strict relation to the discussions which, as we have shown, had been going on for the last eighteen years. At least, if that be not so, why was it purchased at all?

We now come to the plot of ground. It contains 350,000 square feet. What facts have we before us to aid us in answering the question as to whether this plot of ground is sufficient to do for all other sciences what the Natural History Museum does for three? Here, of course, if possible, we must appeal to facts, if facts exist. Let us assume that the new Museum is to be built on the precedent afforded by the Natural History Museum. No. I I 65 , VOL. 45]
The exhibiting space in the Natural History Museum consists of 152 ,000 square feet. To provide this exhibiting space in a building in which, of course, many other things besides exhibiting space have to be considered, the ground plan of the existing building contains an area of 162,000 square feet. The building itself, however, stands in a plot of ground covering about 500,000 square feet, and in this way ample possibilities of future extension are provided.

We are first, then, face to face with the fact that, assuming the Museum which is to do for all the other sciences what the Natural History Museum does for the three named, can, in a few years, be restricted to the same exhibiting area; we begin with a space of, roughly, I 50,000 square feet less for that which must eventually be the larger Museum. Anyone will see that, in the nature of things, it is unlikely that the Museum which has to look after the interests of all the inorganic sciences, and their infinite applications to the arts (by which, of course, the industrial arts are meant), will always remain smaller than that Museum which has to provide for biology chiefly. But the matter, unfortunately, does not end here. It is practically certain that the Royal College of Science will require considerable additions to meet the demands made upon it for science teachers. It is perfectly well known already to all educationists that it has already entirely overflowed the small and ill-contrived building in which it is located; and the Professors of Physics and Geology are already camping out in temporary buildings of the most inconvenient description. We believe it is thoroughly conceded by the Government that new laboratories for physics, astronomical physics, and chemistry must be at once erected. Now, it is perfectly certain that, at this time of day, such laboratories as those, with their various appendages, cannot be erected on a space much less than 100,000 square feet; so that it comes to this, a site already too small for the purposes of a Science Museum and its future extension - if it is to be treated like the Natural History Museum -must have filched from it, for other scientific needs, another slice of $\mathrm{s} 00,000$ square feet.

This may be, perhaps, permitted, because, although the Science Museum may lose in area, it would gain enormously in advantage, for the reason that the teaching in the future may be given in close relation with the instruments which are used in it.

The suggestion that Mr. Tate should be allowed still another I00,000 square feet from this plot-from a plot containing less than 300,000 square feet available for building purposes - of course was preposterous from the beginning, and would have been at once shown to be inspossible if the problem had been considered at all from the region of hard, dry fact. Unfortunately, it was not so considered, and hence an apparent antagonism between the interests of science and art, which has been going on now nearly a year. We have attempted to show that the question is not a question of sympathy-it is a question of fact; and now that the Chancellor of the Exchequer is dealing with the facts, as they ought to have been dealt with in the first instance, there can be no longer any doubt as to which way the issue will be decided.

We believe it is contended by some who are not acquainted with the exact terms of reference to the last 
Treasury Committee that their very indefinite suggestion as to the space to be provided to meet present needs really referred to their view as to the maximum amount of space which a Science Museum should be allowed to cover. We are certain that the scientific members of that Committee would repudiate any such opinion, and they would quote, as we have quoted above, the actual facts concerning the Natural History Museum as negativing any such idea.

Finally, it is advisable to point out the terrible want of any sense of perspective on the part of the Legislature on matters relating to science and art. We do not object to any expenditure the Government may choose to make upon art, but it is our clear duty to point out that the interests of science must not be neglected in order that art may be encouraged. The $£ 70,000$ paid for the land which has given rise to all this discussion is the same sum as that given not long ago for a single picture. The "British Luxembourg"-whatever that may be-which the Government is supposed to be now fostering, was intended to contain most of the pictures now in the South Kensington Museum; so that the edifying spectacle was to have been, or indeed may yet be, seen, of emptying all the pirture galleries at one end of the Museum while $£ 400,000$ of public money is being expended-this has been agreed to by the Government with alacrity-in building new picture galleries at the other. Nor is this all. The Tate Gallery, if built, is to be maintained by the Government : we are informed this will cost at least $£ 4000$ annually. Here, then, is another endowment of, say, $£ \mathbf{r} 60,000$ for art. We do not object to this if the nation so wills it ; but is it wise that all this time the training of our science teachers-our great requisite just now - is to be carried on in sheds, and that the only concern that the Government shows in relation to the Science Museum, which is to include the Patent Museum, is to still absorb year after year the patent fees, which ought in justice to be used for the improvement of our national industries?

\section{CHEMICAL TECHNOLOGY}

Manual of Chemical Technology. By Rudolf von Wagner. Translated and edited by William Crookes, F.R.S., from the thirteenth enlarged German edition, as remodelled by Dr. Ferdinand Fischer. With 596 Illustrations, 968 pages. (London : J. and A. Churchill, I892.)

WHEN a book has reached a thirteenth edition, it may usually be assumed that its form and contents are so familiar to all who are likely to be interested in the subject of which it treats as to require no description, and that it has attained so substantial a reputation as to be independent alike of praise or blame flowing from the pen of the critic. In the case of the book before us, however, the author is no longer living ; and having completed in I880 the eleventh edition of his work, the care of future issues devolves upon others. There is probably no subject which changes so rapidly, owing to the advances of science and the incessant activity of inventors, as chemical technology, or the application of chemistry to useful purposes in the industrial arts ; and a glance at the table of contents of such a book as this is sufficient to remind one of the vast range of subjects with which chemistry has to do. It is the extent and diversity of these subjects which suggests at once the idea of the difficulties which must attend the compilation of such a treatise even when the work of so distinguished a technologist as von Wagner is carried forward by editors so eminent as Dr. F. Fischer and Mr. Crookes. That they have discharged their duty in no perfunctory spirit is evident from the fact that many sections are entirely new, and that, as compared with the eleventh German edition, more than half the text and the illustrations have been replaced by new matter. And further, as pointed out by the English editor, a manual such as this must be in many respects adapted to the conditions of the country where it is written, and, if translated for use elsewhere, it requires modification. The prices of raw materials, of fuel, and of labour, and the laws in different countries have in each case their influence upon the conditions under which chemical industries are carried on. As already remarked, a book in its thirteenth edition must have been found useful by a good many people, but the first thought that passes through the mind in turning over the pages of Wagner's "Technology" is-For whom can this book have been intended? It treats of everything : of fuel and metallurgy, of water, aciás, and alkalies, of pigments and dyes, of glass and cements, of food and fibres, of leather, soap, wood, matches, and many smaller subjects. In the limits of $95^{\circ}$ pages it is not possible to provide all the details essential to each process which would be sought by a manufacturer, and an examination of the volume shows that the treatment of the successive subjects is very unequal. The impression derived from its perusal is that, on the whole, it is most likely to be useful to senior students or to chemists who wish for general information relating to chemical manufactures, but that the efforts which have evidently been made to incorporate into this new edition an account of modern processes are spasmodic, and not always successful

The articles on soda and on chlorine, for example, are among the best in the book. The several processes for the recovery of sulphur from alkali waste, including the Schaffner-Helbig and the Chance patent processes, are described with some detail; and the Weldon-Péchiney process for obtaining chlorine from magnesium chloride is described at length with the aid of numerous illustrations. But even in this latter case, in view of the importance of the process, which is still on its trial, information more recent than December 1887 , might have been expected. There is no reference to more recent processes for electrolyzing alkaline chlorides; but this, perhaps, is expecting too much in the way of the "latest intelligence"; and doubtless the same remark applies to the absence of any description of liquid chlorine as a commercial article. This, however, does not account for the curious error by which the number formerly given as the density of liquid chlorine, I'33, is assigned to the gas. The admirable work of Knietsch (Annalen, 259) on the properties of liquid chlorine deserves to be had in remembrance, more especially as it was done in the laboratory of an alkali-works, with industrial objects in view.

A really unsatisfactory article is that which relates to

NO. I 165 , VOL. 45$]$ 